Research Article

\title{
Environmentally Sustainable Apparel: Recycle, Repairing and Reuse Apparel
}

\author{
Arasinah Kamis, Nornazira Suhairom, Rahimah Jamaluddin, Rodia Syamwil, \\ Farah Najwa Ahmad Puad \\ Universiti Pendidikan Sultan Idris, 35900 Tanjong Malim, Perak Darul Ridzuan \\ Universiti Teknologi Malaysia, 81310 Skudai, Johor \\ Universiti Putra Malaysia, Jalan UPM, 43400 Serdang, Selangor
}

State University of Semarang, Jalan Sekaran, Sekaran, Gunung Pati, Sekaran, Gn. Pati, Kota Semarang, Jawa Tengah 50229, Indonesia

\begin{abstract}
This article intends to present information and awareness to the society regarding issues related the importance of recycling textile and apparels. This is mainly due to the fact that the fashion industry is among the ones that produce great quantity of waste that could lead to environmental pollution. Textile material waste is becoming a common issue in the fashion industry. This happens when drastic changes occur in the fashion industry. Thus, the fashion industry now produces various designs of apparels by offering low prices. Therefore, the consumers are presented with more choices in choosing their clothing style that needs to be disposed and recycled. Due to this, the textile and apparel production should take into consideration the importance of sustaining the environment by producing environment-friendly products that can be recycled. The fashion industry players need to think of effective methods that encourage consumers to buy textile products that can be recycled and re-used. Designers need to be creative and innovative in re-designing apparels which are being recycled. The consumers need to be more positive and show tendency to buy textile products and environmentfriendly apparels that are made of used materials and organic materials such as bamboo, chicken feather fibre and vegetable oil. All the related parties need to work together in order to overcome environmental pollution and this cooperation will ensure proper and effective handling of environmental pollution.
\end{abstract}

Keyword: Recycle, recycled apparels, re-use, environmentally sustainable apparel.

\section{INTRODUCTION}

Borderless world or better known as globalisation have grown wide and this in turn brought development and economic development to many countries. However, these rapid developments also lead to various environmental problems. McDonough and Braungart (2013) stated that measurements need to be taken to solve the world ecological crisis. Human not only need to re-use and recycled resources effectively, but also need to improve the world, the place we live in. They also brought forward the comprehension towards the roles of individuals where each one of us needs to protect the planet from the aftermath of irresponsible human behaviour. They also suggested designing activities to improve the environment. The United States of America has been reported to dispose estimated $£ 68$ apparels a year, mostly at the dump sites (Earth911, nd). Basically, western females buy more clothes and dispose it more frequently compared to males, which means the female clothing supply is seven times more than males (Zurga, Hladnik \& Tavcer, 2015; Muthu, 2014; Claudio, 2007). Apart from that, there are individuals who donate their clothes out of goodwill (Arasinah, Farah Najwa, Rodia \& Emy, 2017b; Zurga et al., 2015, Laitala, 2014, Bianchi \& Birtwistle, 2012; Bristwistle \& Moore, 2007). This is due to the fact that donating clothes to welfare bodies not only help to reduce the burden of the needy people; it also helps in space management at disposal sites and environmental pollution issues.

Apparently, now many used cloth shops have been set up which offers another alternative to used clothes, without having to be disposed; it can be re-used and sold at cheaper prices (Joung \& Park-Poaps, 2013; Thomas, 2008; Arasinah, Ridzwan, Shuhaila, Farah Najwa, 2017a). This is the result of human thinking on how to prolong the usage of clothes by setting up used clothes shop. Used clothes shops are known as bundle shops in Malaysia. In the United Kingdom, these shops are known as Oxfam shops and often operated by charity or welfare bodies as many as 50-75\% (Britwistle \& Moore, 2007). In the United States of America, these shops are known as thrift and goodwill shops, while in Australasia, these shops are known as opportunity (Op) shops. Xu, Chen, Burman, and Zhao (2014) found that more than $90 \%$ respondents in the United States have bought second-hand clothes. Bianchi and Birtwistle (2010) found that women in Scotland and Australia practice selling their used apparels via eBay. They also 


\section{Arasinah Kamis et al / Environmentally Sustainable Apparel: Recycle, Repairing and Reuse Apparel}

explained that these used apparels can be given to poor countries for emergency assistance or sold for recycling purposes.

Apart from this, fashion changes that take place every season causes consumers to be attracted to new fashion designs which in turn leads to high usage of materials. The fashion cycle is too fast and encourages excessive usage of materials. Most women are excited about new fashion and willing to spend money on apparels that they like. Now, consumer quickly become bored with their apparels after few usages and tend dispose it earlier. Gregory (1947) explained that the term "old" refers to apparels that become worn-out too soon, not because it has lost its function but because it has gone out of style. Thus, the consumers are influenced psychologically to replace their fully-functioning apparel. This adds on to the number of used clothes without clear purposes. However, these "old" clothes can still be given a second life with new consumers (XU, 2014). Unfortunately, not many prefer out-ofstyle clothes. As such, disposal of clothes takes place and this gives major impact on the environment because the materials were made of chemicals that can be toxic to the environment and health (Arasinah et al., 2017a; Muthu,2014; Joung \& Park-Poaps, 2013).

Another problem that occurs is the wastage of money in purchasing something that can easily be done right at home. At times, consumers are too carried away with new designs especially things that can be done on own with skills and imagination without any extra cost. Consumers are willing to spend money in order to own something to fulfil their wants. Moreover, some consumers resort to burning their old apparels. This not only contributed to wastage of money but also caused considerable harm to the environment (Wai Yee, Siti Hasnah \& Ramayah, et al., 2016).

\section{A. Excessive Usage of Apparels}

Excessive usage of apparels happen due to fast changing fashion trends, cheaper prices and continuous supply of new designs. About two decades ago, the fashion tempo was fast tuned towards what is called as "quick fashion life cycle". This is a concept manoeuvred by usage, fast changing trend, and low quality. A fashion trend that will be designed, promoted and later on disposed. The consumers tend to buy more due to affordable prices but dispose it after only after one season (Fletcher, 2008). Therefore, quick fashion contributes towards major waste disposal produced by the fashion industry. With increased production quantity, the volume of textile waste also increased drastically (Murray, 2002). McDonough and Braungart (2013) stated that consumers, who have used apparel to the extent where the apparel has torn or bored of it, will just dispose it without thinking of proper disposing method or where it will end up. Thus, information on recycling will educate individuals to recycle for example plastics and papers, but how about apparels? Beard (2008) explained the polarisation among consumers regarding the eco-fashion idea, where consumers could recycle household items like plastic bags and tins but when it comes to fashion, they tend to just dispose it without thinking much.

Bianchi and Birtwistle (2012); Claudio (2007) and Arasinah et al., (2017b), discussed regarding the apparels stored in the consumers' closet being donated to welfare bodies, have increased the rate of donation by $67 \%$ since 2001 . Recycling is one of the methods to reduce excessive material usage apart from cultivating responsibility towards the environment. Birtwistle \& Moore (2007) also found that consumers neither understand nor have knowledge regarding environmental issues that involve man-made fibre and cotton production. The consumers are also deemed to not feel guilty when it comes to disposing expensive materials. They also found that the consumers are less interested in matters related to ethics and social awareness

(Wai Yee, Siti Hasnah, \& Ramayah, 2016).

Usually, cheap apparels tend to wear out easily and thus disposed easily. According to Birtwistle and Moore (2007), the consumers neither understand nor have knowledge regarding environmental issues that involve man-made fibre and cotton production they also found that the consumers are not interested in social ethics and they knew that the quality of produced apparels were high. Sull \& Tuconi (2008), on the other hand, found that the designers appreciate speed and fashion that can be easily disposed. The research of Byun and Sternquist (2011) found that fashion designers are aware that speed and destruction in the fashion world, but they also know that when recycled materials are used to produce a certain fashion, the consumer will not buy it. They are more interested in new products. The production of new fashion will stimulate the consumers' senses to purchase it.

\section{B. Creativity}

Creativity needs to be emphasized in producing new designs or modifying current designs into other designs (innovative). According to Brougher and Rantanen (2009), creativity is the ability to think, take action, produce something original, innovative and the individual needs to be highly imaginative. The skill exists when and individual has high degree of innovative, different thinking and willingness to take risk. Lee and Jirousek (2015) stated that creativity is an important component in producing an innovative idea in the process of designing where it generates inspiration and idea. The creative evaluation of a product often comes up in creativity researches. Thus, creative individuals need to be aware of the market needs. They also must to be able to translate their creativity into designs that are appropriate and accepted widely now and in the future (Karpova, Marcketti \& Barker, 2011a); Karpova, Marcketti \& Barker (2011b); Mete (2006). Lapolla and Sanders (2015) in their research on female respondents aged between 21-60 years old where these women use their creativity by re-using and repairing their used apparels. This was meant to reduce textile wastage problem.

Meanwhile, the research of Karpova, Marcketti and Kamm (2013) found that creative individuals have the determination, 
different thinking, willingness to take risk and open minded. Research by Black, Freeman and Stumpo (2015); Lubart (2001); Ryan and Brown (2012) looked into the Conceptual Model of Creative Thinking in designing apparels and creative thinking strategies. This model comes with the aspects of preparation, hibernation, lighting and validation. The research of Valgeirsdottir, Onarheim and Gabrielsen (2015) found that creativity is an important factor in evaluating a product such as purchase, the importance of creative design and emphasize on importance of creative process. Creativity also is an important aspect for future graduates in order to be able show involvement in fashion industry careers (Arasinah, Ab Rahim, Ramlah, Soaib \& Norhaily, 2013; Arasinah, Ab Rahim, Ramlah \& Soaib, 2014; Arasinah, Ab. Rahim, Ramlah, Soaib, Zaliza, 2015).

Mete (2006) also indicated that the aspect of generating creative ideas alone is not sufficient and new inspiration resources need to be found in order to create designs that carry better significance, quality and mostly commercial values. Strickfaden, Stafiniak and Terzin (2015) found that developing creative ideas by the influence of inspirational resources is the most aspect during the process of designing apparel. Creativity also increases the problem solving skill (Im, Hokanson \& Johnson, 2015). According to Koo, Dunne, Bye (2014), a design of an apparel should take into account aspects such as function (can be matched easily, comfortable, usability), easy care, durability, longer usage period, hedonic (interesting and can be matched with varioud styles) and social (polite). In the research of Cao, Wool, Bonanno, Dan, Kramer and Lipschitz (2014), it was found that design of a textile product must take into account the aspect of usability, multiuse and practicality. Thus, Koberg and Bagnall (1981) determined three steps in the process of designing which are the process of receiving, analysing, determining, developing significance, choices, implementation, and evaluation.

\section{ROLES OF FASHION DESIGNERS AND MANUFACTURER}

Fashion designers are deemed to influence almost $80 \%$ of product production that affects the environment (Yulpisman, 2012). They are supposed to be a part of the problem solving mechanism but unfortunately the awareness of the importance of nurturing the environment is less implemented in most Asian countries. Malaysian fashion designers and textile manufacturers still don't give importance to the environmental issues in textile production. If the environmental issues are not managed soon, it will soon become a threat to natural resources and ecosystem which indirectly will threaten the human health. Thus, one of the ways to solve this is by reducing the usage of chemicals in the process of textile production and the textile waste are processed and re-used. Apart from that, continuous civic awareness campaigns should be increased (Mostafa, 2006; Laroche, Bergeron, \& BarbaroForleo, 2001). Textile and apparel industry in foreign countries specifically have started to emphasize the aspect of environmental-friendly in their production in order to increase demand and provide awareness regarding environmental- friendly products (Muthu, 2014; Young, Hwang, McDonald, \& Oates, 2010; Ali \& Sarwar, 2010). Designers also need to be aware on the importance of producing textile products that can be reused or recycled.

Few foreign researches suggested that the manufacturers look for effective ways to encourage consumers to buy textile products that can be recycled. The researches of Zheng and Chi (2015); Grasso, McEnally, Widdows and Herr (2000); Yan and $\mathrm{Xu}$ (2010) also found that the attitude of consumers are now more positive and tend to buy textile products or apparels that are environmental-friendly and can be recycled. There are also researches that found that consumers have started to realise the advantage of apparels made of organic materials such as bamboo, chicken feather fibre and vegetable oil (Hwang, Lee \& Diddi, 2015; Cao, Wool, Bonanno, Dan, Kramer \& Lipschitz, 2014).

\section{Textile Waste Management Method}

The report from disposal sites in Hong Kong found that an average of 234 tonnes of textile waste is being disposed every day. Thus, the NGO is trying to overcome this problem with the support of Hong Kong government. Local enforcement recorded that their country is among the largest fashion product manufacturer in the world. The fashion industry produces excessive waste that causes environmental pollution. Waste materials from textile production have become a common issue in the fashion industry. China's manufacturing factories makes up about $40 \%$ of the world textile factories and about $30 \%$ of apparel factories of the world. Malaysia is not excluded from this textile waste problem. However, in Malaysia, a proud achievement was the innovation of Malaysia University of Kelantan in the year of 2012 by Dr. Wong Yee Ching, who used the agriculture waste which was paddy husk in the process of treating textile industrial waste from batik to protect the environment from continuous pollution (Yulpisman, 2012).

The concept of waste hierarchy refers to $3 \mathrm{R}$ - reduce, re-use and recycle; that classifies the waste management method according to their preferences. This means that the waste production needs to be avoided and reduced. Waste produced needs to be processed by re-use, recycle and other recycling options that can reduce disposal operations at the disposal sites (Wei et al., 2016; Joung, Park-Poaps, 2013). In the textile fashion industry, the aim of the waste hierarchy is to maximise the benefits of apparels while minimising waste production that affects the environment (Muthu, 2014). One of the approaches in implementing $3 \mathrm{R}$ in the textile fashion is by reducing purchase and use. "The of zero waste" concept put forward by Gwilt and Rissanen (2011); Carrico and Kim (2014) in the process of fashion design is that there are no waste at all after the pattern is cut. In another way, by reducing which is to improve and repair, either as a whole product or for certain parts of the product, to ensure that the consumers will use the product as long as possible (Fletcher, 2008).

\section{Recycle}




\section{Arasinah Kamis et al / Environmentally Sustainable Apparel: Recycle, Repairing and Reuse Apparel}

Recycle means ruined materials are repaired, re-designed, or re-used in other conditions (Ekstrom \& Salomonson, 2014). Recycling is "optimising the process of material usage in any ways such as waste being turned inti raw materials for nature or any other industry" (McDonough \& Braungart, 2013). Gwilt and Rissanen (2011) found few opinions from the designers that defined recycling as when someone can determine the real value of waste material through transformation during designing and manufacturing. Recycling activities are among the activities that contribute towards the sustainability of the environment that is able to reduce destruction of nature and reduce the usage of raw materials to create new things which is efficient because it can be used multiple times before disposal. Meanwhile the word upcycling and the antonym downcycling mean variation of recycling that are normally related to reducing wastage and reuse everything that we dispose. Ngack (2011) and Arasinah et al., (2017a) also defined recycling as re-use of disposed materials to develop a product that has higher value compared to the original product.

According to the National Solid Waste and Public Cleansing Management Act 2007 (Act 672), recycling means collecting and separating wastes in order to produce products that are valuable. Recycling happens when disposed materials are processed to produce same product or new products. Recycling process can reduce waste products, reduce usage of new raw materials, reduce usage of energy, reduce pollution (water and air) and reduce production of greenhouse gas. Materials that can be recycled are plastics, textiles, papers, glasses, metal and electronics. For example, in the year of 1813, Benjamin Law introduced the process of transforming balance cloths into thread (Lucy, 2006). Meanwhile, re-use means to use again used products either for the same previous purposes or for new purposes. Re-use can help save time, money, resources and energy. The recycling process takes only little energy where it indirectly can help in nurturing the environment for the future generation. Among the ways to recycle are by buying products that can be recycled or buying products that are made of recycled materials (Solid Waste and Public Cleansing Department, 2015).

The current trend shows that disposed apparels being transformed into different styles are considered recycling. Although few authors call it trend, others consider it as a movement that is permanent here. In the book "Sustainable Fashion and Textiles", Fletcher and Grose (2012) defined recycling as "adding value through brilliant ideas". Meanwhile, Murray (2002) described recycling as "not merely nurturing of resources that enters into the production of certain things, but adding value to its content", by using knowledge in carrying out the re-designing activities. Thus, if an individual able to add value, economy, intellectual, emotion, material of a product through the process of re-use, it can be called as upcycle. In that book also, a common term was mentioned regarding upcycle (McDonough \& Braungart, 2013). The elegance in recycling comes from the recycling skills and not from "hippie" fashion which is the continuation of the 60's, but a design that is beautiful.

\section{E. The tendency to buy environmentally-friendly product}

The consumers now are starting to become aware of the importance of protecting the environment by purchasing textile products and apparels that can be recycled (Sonnenberg, Jacobs, Momberg, 2014; Wai Yee, 2016). Apart from that, fashions retailers should play their roles to encourage the culture of using environmentally-friendly products and green products. Green marketing campaigns and green awareness also have major influence in cultivating green awareness and indirectly influence the consumers' behaviour towards going green (Lee, Choi, Youn \& Lee, 2012). The consumers also need deep understanding regarding the risks involved in purchasing and using products that does not pollute the environment from the aspects such as finance, product performance, psychology and social risks. This aims to reduce the effects on the environment when it comes to purchase and usage of apparels (Kang \& Kim, 2013). The research of Cao, Wool, Bonanno, Dan, Kramer and Lipschitz (2014) was related to usage of environmentally-friendly materials that are used to produce shoes and coats. Both these products were well-received by the consumers. Materials used are from bio-based resources such as vegetable oil, natural cloth fibre, and chicken feather fibre. This is due to the fact that the usage of bio-based materials in the production of apparels and shoes are able to reduce the industries' dependency on petroleum resources and able to solve environmental pollution issues. There are few researches in foreign countries that found the consumers are more aware on the importance of buying textile products made of organic materials such as bamboo, chicken feather fibre and vegetable oil. This is due to the high level of awareness among consumers regarding the importance of protecting the environment (Hwang, Lee \& Diddi, 2015; Yoo, Divita \& Kim, 2013).

As mentioned in the fashion blog by Erica (2016) known as "fashion recycled", which puts used apparels on auctions to be sold to charity shops, car boot sales, garage stores, thrifts stores and vintage store. This blog was developed as a way to network the whole world and provide information regarding recycling fashion, fashion styles, fashion ethics, shopping at second-hand shops and more. Figure 1,2 and 3 illustrates designer Creolesha designing apparels from recycled apparels such as different types of arms being cut and combined together as skirts.

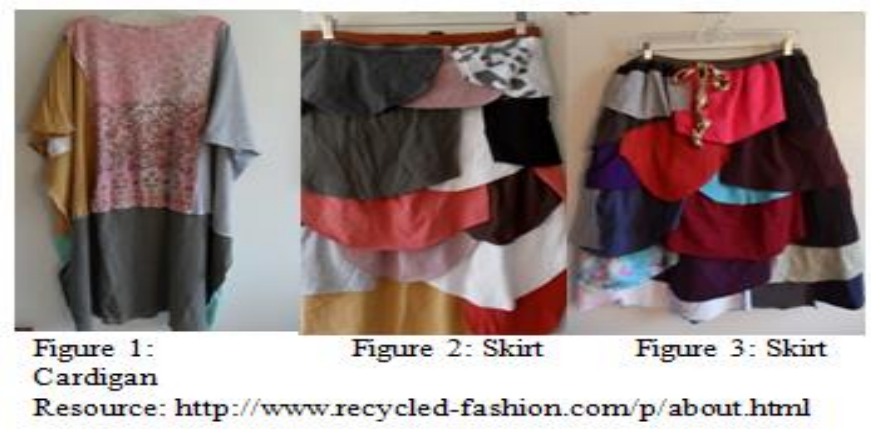




\section{Arasinah Kamis et al / Environmentally Sustainable Apparel: Recycle, Repairing and Reuse Apparel}

Meanwhile, Preloved (2016) uses vintage fabrics as one of their fashion design. Their online business and boutique produces recycled apparels for women, children and household furnitures with more than 400 shops. As of previous season, they made sweaters out of wool for shops in America. Apart from that, they also produced skirts that can be matched recycled wool pants and similar skirts that made of wool. It was found that even celebrities bought these products such as Julia Roberts, Daria Werbowy, Kate Hudson, and Christine Horne. Their designs sometimes combine old and new fabrics in one apparel. The apparels are often price between the range of $\$ 100-\$ 200$ (Figure 5) and the skirts are sold in retail priced at $\$ 149$ (Figure 4).

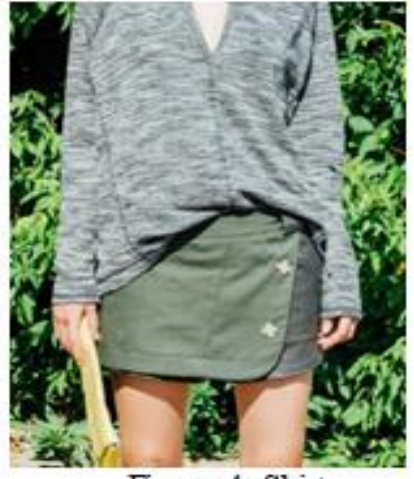

Figure 4: Skirt

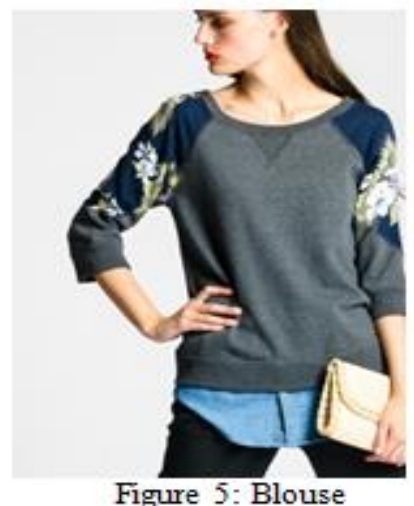

Resource:

http://www.preloved.ca/shop/index.php?main_page=product _info\&products_id $=359$

Among others are Asiatica (2016), a company that produces apparels from Japanese kimono. Figure 6 and 7 illustrates the apparel designs produced which are luxurious and fashionable where they combined Japanese silk with recycled apparels (mixed vintage Japanese). They visit Japan twice a year to choose recycled materials. Apparels sold normally priced about 1450 USD

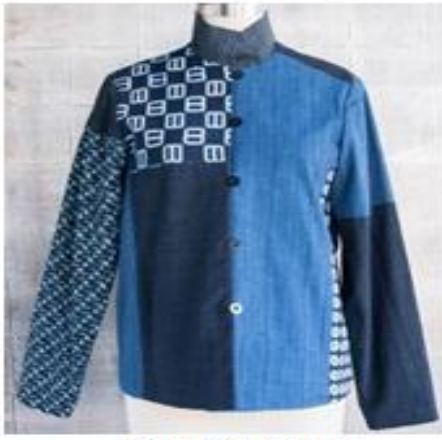

Figure 6: Jacket

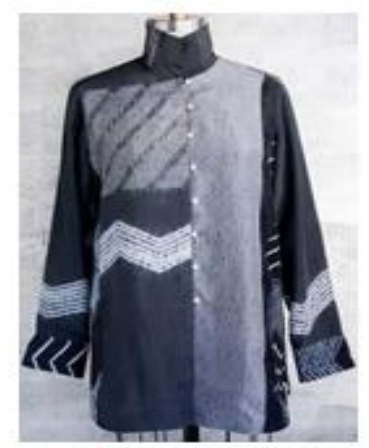

Figure 7: Blouse
Resource: http://www.asiaticakc.com/?p=1933

Styling Junky (2016) in London, came up in the Vogue magazine and known for its innovative designs that are of high quality designed from second-hand men clothes made into women fashion apparels (Figure 8). The company also ensures that there are no same design apparels, could be from same pattern but made of different fabric. The recycled textile materials are obtained from second-hand shops. They also published a book by the name of "Junky Styling -Wardrobe Surgery" where they frequently recycle (upcycling) wardrobes. The customers can bring few old wool coats and the designers will design something new and according to current fashion. The artful and attractive apparel designs of this company were highlighted in the art exhibitions around the world and in permanent collection in the Museum of Design, London.

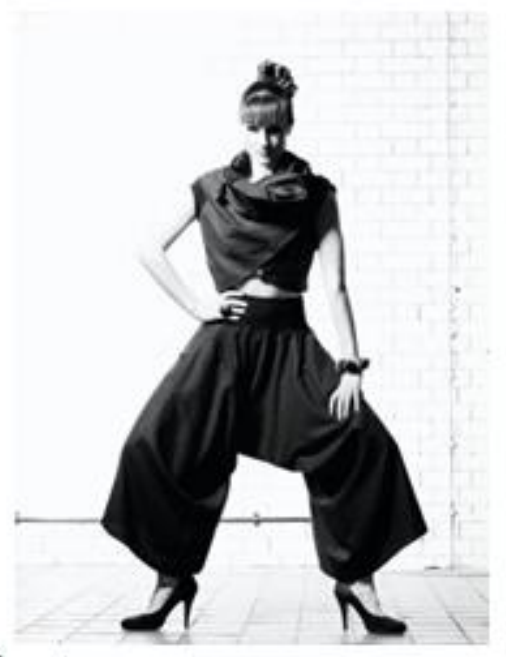

Figure 8: Sweater

Resource: http://junkystyling.blogspot.com

Another fashion designer, Sophie (2016) from France, sells apparels through her blog. Figure 9 shows the sweater made from recycled men clothes (recycled men sweater). She also shares information regarding how she obtains design ideas and apparel cutting. She is also involved in fashion shows to promote recycled apparel designs.

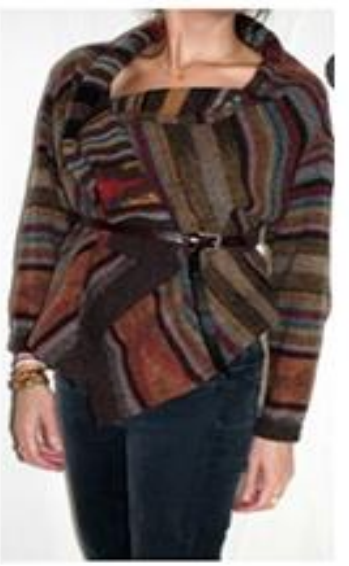

Figure 9: Sweater

Resource: http://www.bysophieb.com/2013/01/winter-13refashioning-of-mans-sweater.html

Figure 10 shows hand-made saree scarf made from $100 \%$ recycled saree (Uncommongoods, 2016). This scarf can be used as head scarf, the saree was cut into straps and handsewn. The scarves have various unique colour combinations, different patterns and swirled to get beautiful and wavy texture. These scarves can be worn on the shoulders or head.
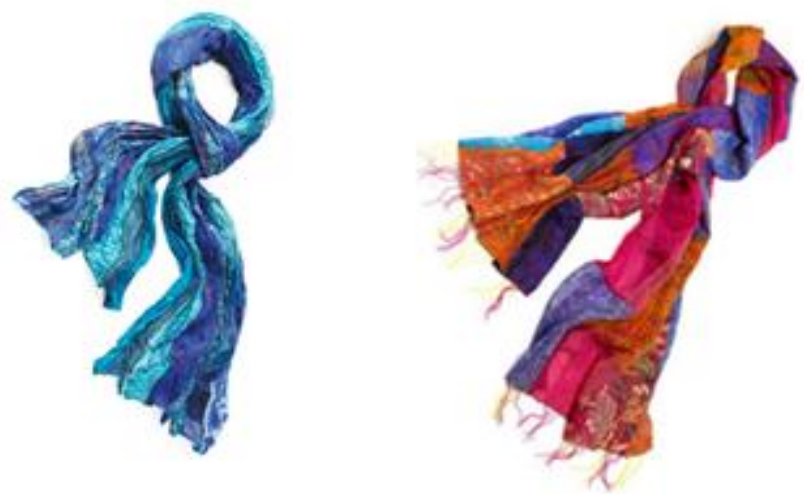
Figure 10: Saree Scarf

Resource: http://www.uncommongoods.com/product/sariscarf

Figure 11 shows soft scarf T-shirt made in America. It was made from disposed T-shirts that are collected from apparel companies.these sacrves are sewn by disabled individuals who learned to sew as a means to help them be independent.

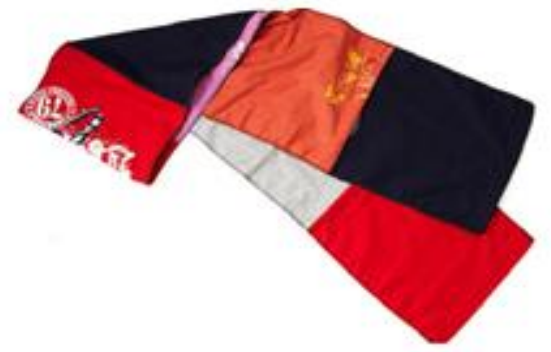

Figure 11: T-shirt Scarf

Resource: http://www.uncommongoods.com/product/sariscarf

\section{Related Theories}

\section{F. Apparel Life-cycle}

The apparel life-cycle stars from the stage of raw material processing, distribution or selling, usage, and the direction of apparel after the expiry (Carneiro, Refosco, \& Soares, 2016; Gwilt, 2014; Downer \& Cassidy, 2012). Zurga, Hladnik and Tavcer (2015) stated that every stage of life-cycle contributes toward environmental pollution. Thus, the apparel life-cycle is very important in creating awareness among the consumers regarding its influence in achieving fashion sustainability. Apart from that, fashion sustainability also is influenced by the behaviour of consumers in making decisions to purchase apparels, use the apparels, maintain it, and finally dispose those apparels (Carneiro et al., 2016). According to Fletcher (2008), apparel life-sycle starts with designing, product, distribution, usage and expiry. Figure 12 illustrates Apparel Life-cycle developed by Fletcher (2008). Laitala (2014) stated that average life expectancy of an apparel in the wardrobe is only about 4-5 years and among the reasons for disposals are incompatible sizes, lack of apparel storage space, out-of-trend apparels, fabric worn out, and non-functional to the user. Textile wastage can be classified into two which are pre-waste textile and post-waste textile. Pre-waste textile is wastage from textile industries, fibres and cotton, while post-waste textile is textile that that already passes through the consumer market and recycled into different products.

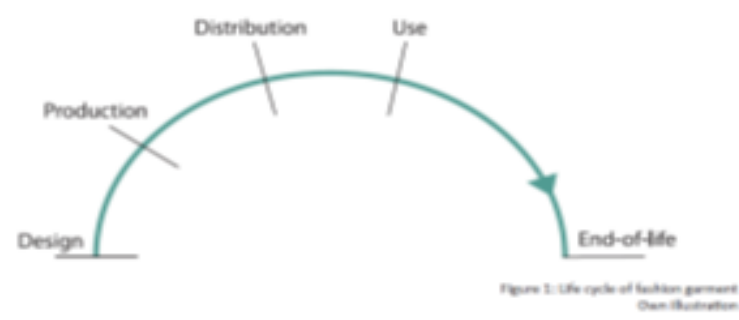

Figure 12: Apparel Life-cycle
Normally, apparel life-cycle is closely connected to the wardrobe metabolism. Wardrobe metabolism is how the apparel life starts from the second it was purchased from retailer or other resources or it was disposed or taken out from consumers' apparel stock (Xu, 2014). Fletcher and Grose (2012) concluded wardrobe metabolism in the Figure 13, simultaneously with the apparel life-cycle.

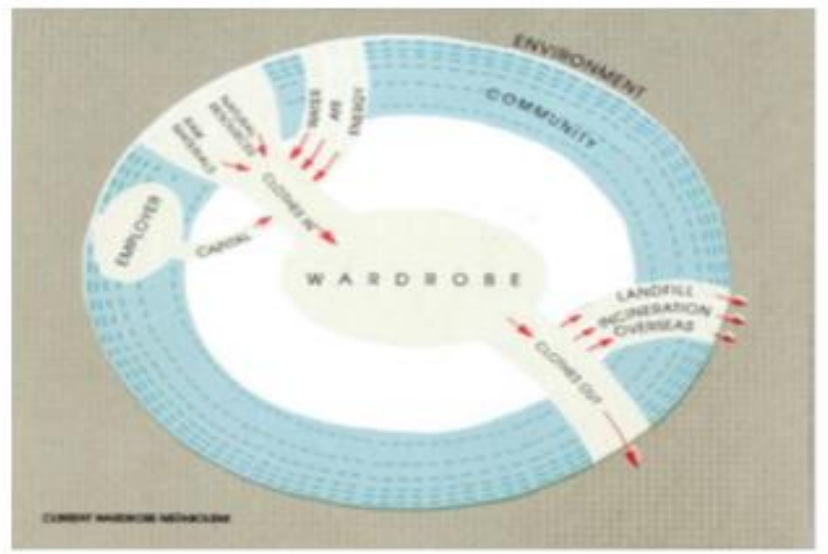

Figure 13 : Current wardrobe metabolism by Fletcher and Grose (2012)

\section{Activating the Circle}

This section is related to current suggestion to develop apparels' linear life into real cycle where the consumers and the business share the synergy in them and with each other, acting as co-variable, working towards usage and usage process that is more effective. Figure 14 is the graphic illustration of how future wardrobe metabolism look like to be more effective.

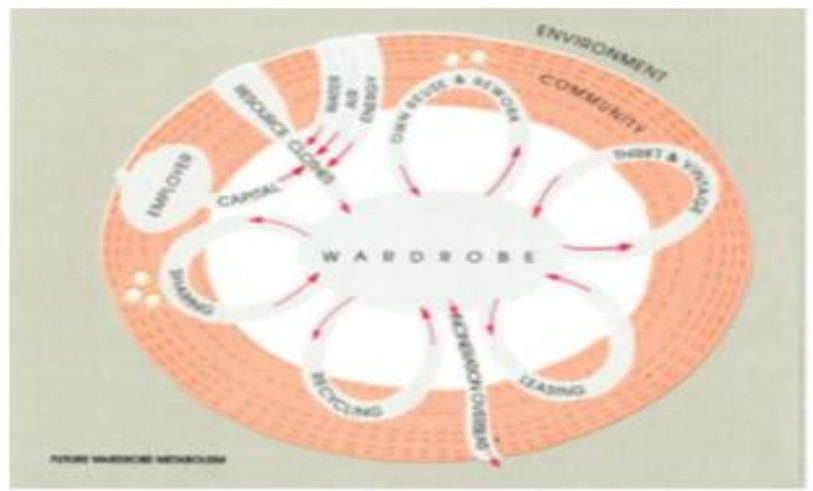

Figure 14: Future wardrobe metabolism by Fletcher and Grose (2012)

\section{CONCLUSION}

Waste materials such as textile products can be re-used to produce different textile products that have multiple uses. Apart from that, as a way of creating awareness and develop positive attitude among consumers and also designers and manufacturers regarding the importance of nurturing the environment. Awareness is presented among consumers by purchasing products that can be recycled or products that are made from recycled materials. The society need to be aware regarding the importance of recycling for the benefit of environmental sustainability. If not, recycling practice will be forgotten and only destruction will happen. Apart from that, the usage of existing materials such as new raw materials for new products can be reduces which in turn reduces usage of energy, air pollution, water pollution and production of carbon dioxide. Zero-waste is the philosophy that encourages re-use 
of materials where waste being disposed at the disposal sites are minimised. Recycling activities work as additional measure towards achieving zero-waste.

Thus, the government needs to enforce laws related to aspects of environmental cleanliness. This is very significant as a step to protecting the environment. As the implication, the laws need to be made even stricter in order to reduce environmental pollution. The waste materials can be re-processed to be used again. Through this method, natural resources such as trees that are being used to acquire raw materials in order to fulfil the basic needs of human can be reduced. Apart from that, the country could also save its cost in acquiring human needs and at the same time able to protect the environment. As conclusion, recycling program is one of the ways to overcome environmental pollution. There are few methods that can be apllied in order to solve pollution problems. Pollution needs to be addressed quickly since it has many implications on the society and country. All the related parties need to work hand in hand to solve environmental pollution issues. With good cooperation from all the related parties, it can be assured that environmental pollution can be handled well.

\section{ACKNOWLEDGEMENTS}

The author is grateful to the Universiti Pendidikan Sultan Idris for the funding of this project. The author would also like to express her appreciation for the constructive comments given by an anonymous reviewer.

\section{REFERENCES}

[1] Ali, M. A., \& Sarwar, M. I. (2010). Sustainable and environmental friendly fibers in textile fashion: A study of organic cotton and bamboo fibers. (Doctoral dissertation). University of Boras, Boras.

[2] Arasinah Kamis, Ab Rahim Bakar, Ramlah Hamzah, Soaib Asimiran and Norhaily Abdul Halim. (2013). Competency Assessment of Clothing Fashion Design: Rasch Measurement Model for Construt Validity and Reliability. Journal of Technical Education and Training, 5 (2), 1-13. ISSN: 2229-8932.

[3] Arasinah, K, Ab. Rahim, B, Ramlah, H, Soaib, A, Zaliza, H. (2015). Using Rasch Model and Confirmatory Factor Analysis to Assess Instrument for Clothing Fashion Design Competency. International Journal of Social Science and Humanity, 5 (5), 418-421. ISSN: 2010-3646.

[4] Arasinah Kamis, Ab Rahim Bakar, Ramlah Hamzah, Soaib Asimiran. (2014). Validity and Reliability of Clothing Fashion Design (CFaDC) Competency Instrument. Middle- East Journal of Scientific Research 19 (Innovation Challenges in Multidiciplinary Research \& Practice): 89-97. ISSN 1990-9233. DOI: 10.5829/idosi.mejsr.2014.19.icmrp.14

[5] Arasinah Kamis, Ridzwan Che Rus, Shuhaila Nahrawi, Farah Najwa Ahmad Puad. (2017a). Fesyen Pakaian Dimanakah Ianya Berakhir?. Dalam Penyelidikan dalam Sains Rumah Tangga (pp.1-10). Tanjung Malim: Penerbit Universiti Pendidikan Sultan Idris. ISBN: 978-9672163-07-7.

[6] Arasinah Kamis, Farah Najwa Ahmad Puad, Rodia Syamwil \& Emy Budiastuti. (2017b). Kelestarian Tingkah Laku Melupuskan Pakaian. Dalam Penyelidikan dalam Sains Rumah Tangga (pp.11-25). Tanjung Malim:
Penerbit Universiti Pendidikan Sultan Idris. ISBN: 978967-2163-07-7.

[7] Asiatica (2016. Access from http://www.asiaticakc.com/?p=1933

[8] Beard, N. D. (2008). The branding of ethical fashion and the consumer: A luxury niche or mass market reality? Fashion Theory, 12 (4), 447-468.

[9] Bianchi, C., \& Birtwistle, G. (2012). Consumer clothing disposal behaviour: A comparative study. International Journal of Consumer Studies, 36, 335-341. doi:10.1111/j.1470-6431.2011.01011.x.

[10] Birtwistle, G., \& Moore, C. M. (2007). Fashion clothing where does it all end up?. International Journal of Retail \& Distribution Management, 35(3), 210-216. Doi: http://dx.doi.org/10.1108/09590550710735068

[11] Black, C., Freeman, C., \& Stumpo, G. (2015). Conceptual model and strategies for creative thinking in apparel design. International Journal of Fashion Design, Technology and Education, 8 (2), 131-138. doi: 10.1080/17543266.2015.1018958.

[12] Byun,S. \& Sternquist, B. (2011). Fast fashion and in-store hoarding: The drivers, moderator, and consequences. Clothing and Textiles Research Journal, 29(3), 187-201.

[13] Claudio, L. (2007). Waste couture: Environmental impact of the clothing industry. Environmental Health Perspectives, 115(9), A448-A454.

[14] Cao, H., Wool, R. P., Bonanno, P., Dan, Q., Kramer, J., \& Lipschitz, J. (2014). Development and evaluation of apparel and footwear made from renewable bio-based materials. International Journal of Fashion Design, Technology and Education, 7 (1), 21-30. doi: 10.1080/17543266.2013.859744

[15] Carrico, M., \& Kim, V. (2014). Expanding zero-waste design practices: a discussion paper. International Journal of Fashion Design, Technology and Education, 7 (1), 5864. doi: 10.1080/17543266.2013.837967

[16] Carneiro N., Refosco E., and Soares G. (2016). Contribution to an Efficient Transmission of Information to the Textile Fashion Consumer and the Influence in Sustainable Attitudes. The 90th textile institute world conference. Textiles: inseparable from the human environment 25-28 April 2016. Poznan, Poland.

[17] Downer, E. F., \& Cassidy, T. D. (2012). Cycle clothing from a lifestyle perspective in the UK's contemporary marketplace. International Journal of Fashion Design, Technology and Education, 5 (1), 33-43. doi: 10.1080/17543266.2011.597786

[18] Earth911 (n.d.). Retrieved from http://earth911.com/style/reet-aus-upcycled-clothing/

[19] Ekström, K. M., \& Salomonson, N. (2014). Reuse and recycling of clothing and textiles-A network approach. Journal of Macromarketing, 34, 383-399. doi:10.1177/0276146714529658

[20] Erica, (2016).

fashion.com/p/about.html 
Arasinah Kamis et al / Environmentally Sustainable Apparel: Recycle, Repairing and Reuse Apparel

[21] Fletcher, K. \& Grose, L. (2012). Fashion and sustainability: Design for change. London, United Kingdom: Lawrence King Publishing Ltd.

[22] Fletcher, K., 2008. Sustainable Fashion and Textiles: Design Journeys. London, Earthscan.

[23] Grasso, M. M., McEnally, M., Widdows, R., \& Herr, D. G. (2000). Consumer Behaviour toward Recycled Textile Products. Journal of the Textile Institute, 91 (2), 94-106. doi:10.1080/00405000008659530

[24] Gwilt, A., \& Rissanen,T. (Ed.). (2011). Shaping sustainable fashion: Changing the way we make and use clothes. London, England: Earthscan.

[25] Gwilt, A., 2014. A Practical Guide to Sustainable Fashion. London, Bloomsbury.

[26] Hwang, C. G., Lee, Y. A., \& Diddi, S. (2015). Generation Y's moral obligation and purchase intentions for organic, fair-trade, and recycled apparel products. International Journal of Fashion Design, Technology and $\begin{array}{llll}\text { Education, } & 8 & \text { (2), } & \text { 97-107. }\end{array}$ $10.1080 / 17543266.2014 .996917$

[27] Im, H., Hokanson, B., \& Johnson, K. K. P. (2015). Teaching creative thinking skills: A longitudinal study. Clothing and Textiles Research Journal, 33 (2), 129-142. doi: $\quad 10.1177 / 0887302 X 15569010$.

[28] Jabatan Perangkaan Malaysia. (2015). Laporan Tinjauan Kajian Rancangan Struktur Negeri Selangor 2035: Penduduk dan sumber manusia. http://www.mbsa.gov.my/msmy/Documents/Laporan\%20Tinjauan\%20Selangor\%2020 35/A2.0_PendudukTinjauan.pdf

[29] Joung, H.-M. and Park-Poaps, H. (2013), Factors motivating and influencing clothing disposal behaviours. International Journal of Consumer Studies, 37: 105-111. doi:10.1111/j.1470-6431.2011.01048.x

[30] Junky Styling (n.d.). Retreived from http://junkystyling.blogspot.com/

[31] Kang, J. and Kim, S.-H. (2013), What are consumers afraid of? Understanding perceived risk toward the consumption of environmentally sustainable apparel. Family and Consumer Sciences Research Journal, 41 (3), 267-283. doi: 10.1111/fcsr.12013

[32] Karpova, E., Marcketti, S., \& Kamm, C. (2013). Fashion industry professionals' viewpoints on creative traits and, strategies for creativity development. Thinking Skills and Creativity, 10, 159-167. doi: 10.1016/j.tsc.2013.09.001

[33] Karpova, E., Marcketti, S. B., \& Barker, J. (2011a). The efficacy of teaching creativity: Assessment of student creative thinking before and after exercises. Clothing \& Textiles Research Journal, 29 (1), 52-66. doi: 10.1177/0887302X11400065.

[34] Karpova, E., Marcketti, S. B., \& Barker, J. (2011b). Putting the puzzle together: Apparel professionals' perspectives on creativity. International Journal of Fashion Design, Technology and Education, 4 (2), 103 113. doi: 10.1080/17543266.2010.542185

[35] Khar, S. S., \& Ayachit, S. M. (2013). Looking backwards to go forward - use of traditional Indian pattern making to develop contemporary methods for global fashion.
International Journal of Fashion Design, Technology and $\begin{array}{llll}\text { Education, } & 6 & \text { (3), } & 181-189 .\end{array}$ 10.1080/17543266.2013.815808

[36] Koberg, D., \& Bagnall, J. (1981). Universal Traveler: A Soft Systems Guide to: Creativity, Problem Solving and The Process of Reaching Goals. California: William Kaufmann Inc.

[37] Koo, H. S., Dunne, L., \& Bye, E. (2014). Design functions in transformable garments for sustainability. International Journal of Fashion Design, Technology and Education, 7 (1), 10-20. $10.1080 / 17543266.2013 .845250$

[38] Laitala, K. (2014). Consumer's clothing disposal behavior - a synthesis of research results. International Journal of Consumer Studies, 38, 444-457.

[39] Lapolla, K., \& Sanders, E. B. N. (2015). Using Co creation to Engage Everyday Creativity in Reusing and Repairing Apparel. Clothing and Textiles Research Journal, $33 \quad$ (3), 183-198. doi: $10.1177 / 0887302 X 15572877$

[40] Laroche, M., Bergeron, J., \& Barbaro-Forleo, G. (2001). Targeting consumers who are willing to pay more for environmentally friendly products. Journal of Consumer Marketing, 18 (6), 503-520.

[41] Lee, J. S., Jirousek, C. (2015). The development of design ideas in the early apparel design process: a pilot study. International Journal of Fashion Design, Technology and Education, 8 (2), 151-161. doi: 10.1080/17543266.2015.1026411

[42] Lee, N., Choi, Y. J., Youn, C., \& Lee, Y. (2012). Does Green Fashion Retailing Make Consumers More Ecofriendly?: The Influence of Green Fashion Products and Campaigns on Green Consciousness and Behaviour. Clothing and Textiles Research Journal, 30 (1), 67-82. doi:10.1177/0887302X12446065.

[43] Lucy, S. (2006). Recycle: The essential guide. Black Dog Publishing. London, UK: Black Dog Publishing. ISBN 1904772366.

[44] McDonough, W., \&., Braungart, M. (2013). The upcycle: Beyond sustainability-designing for abundance. New York, NY: North Point Press. ISSBN: 978-0865477483.

[45] Mete, F. (2006). The creative role of sources of inspiration in clothing design. International Journal of Clothing Science and Technology, 18 (4), 278-293. doi: 10.1108/09556220610668509

[46] Mostafa, M. (2006). A hierarchical analysis of the green consciousness of the Egyption consumer. Psychology \& Marketing, 24 (5), 455-473.

[47] Murray, R. (2002). Zero waste. Greenpeace Environmental Trust. Akses daripada http://www.zerowasteeurope.eu/wpcontent/uploads/2011/04/zero-waste-by-robin-murray.pdf

[48] Muthu, M. (2014). Assessing the Environmental Impact of Textiles and the Clothing Supply Chain. Woodhead Publishing. ISBN 9781782421047.

[49] Ngack, C. (2011, Aug. 29). Retweet, sexting and cyber bullying added to the Oxford English Dictionary. CBS News. Retrieved 
http://www.cbsnews.com/news/retweet- sexting-andcyberbullying-added-to-oxford-english-dictionary/

[50] Perbadanan Pengurusan Sisa Pepejal \& Pembersihan Awam. (2015). Akses daripada http://www.ppsppa.gov.my/v3/index.php/3r/recycle-kitarsemula

[51] Preloved (2016).

Akses daripada http://www.preloved.ca/shop/index.php?main_page=prod uct_info\&products_id=359

[52] Sophie B. (2016). Akses daripada http://www.bysophieb.com/2013/01/winter-13refashioning-of-mans-sweater.html

[53] Strickfaden, M., Stafiniak, L., \& Terzin, T. (2015). Inspired and inspiring textile designers: Understanding creativity through influence and inspiration. Clothing and Textiles Research Journal, 33 (3), 213-228. doi: $10.1177 / 0887302 \times 15578263$

[54] Sull, D. \& Turconi, S. (2008). Fast fashion lessons. Business Strategy Review, 19(2), 4-11.

[55] Sonnenberg, N., Jacobs, B., Momberg, D. (2014). The Role of Information Exposure in Female University Students' Evaluation and Selection of EcoFriendly Apparel in the South African Emerging Economy. Clothing and Textiles Research Journal, 32 (2), 266-281. doi:10.1177/0887302X14541542.

[56] Thomas, S. (2008). From "green blur" to eco fashion: Fashioning an eco-lexicon. Fashion Theory, 12(4), 525-540.

[57] Uncommongoods (2016). Akses daripada http://www.uncommongoods.com/product/sari- scarf

[58] Uncommongoods (2016). Access from http://www.uncommongoods.com/product/reclaimed-tshirt-scarf

[59] Valgeirsdottir, D., Onarheim, B., \& Gabrielsen, G. (2015). Product creativity assessment of innovations: considering the creative process. International Journal of Design Creativity and Innovation, 3 (2), 95-106. doi: 10.1080/21650349.2014.954626

[60] Wai Yee, L., Siti Hasnah Hassan, \& Ramayah, T. (2016). Sustainability and philanthropic awareness in clothing disposal behavior among young Malaysian consumers. SAGE Open, pp. 1-10.

[61] Xu, Y., Chen, Y., Burman, R. \& Zhao, H. (2014). Second-hand clothing consumption: a cross-cultural comparison between American and Chinese young consumers. International Journal of Consumer Studies, 38, pp. 670-677.

[62] Yan, R.-N., \& Xu, H. (2010). Understanding green purchase behaviour: College students and socialization agent. Journal of Family and Consumer Sciences, 102 (2), 27-32.

[63] Young, W., Hwang, K., McDonald, S., \& Oates, C. J. (2010). Sustainable consumption: Green consumer behaviour when purchasing products. Sustainable Development, 18 (1), 20-31.

[64] Yoo, J. J., Divita, L., \& Kim, H. Y. (2013). Environmental awareness on bamboo product purchase intentions: do consumption values impact green consumption?. International Journal of Fashion Design, Technology and Education, 6 (1), 27-34. doi: 10.1080/17543266.2012.758318

[65] Yulpisman Asli. (2012). Rawat sisa kumbuhan tekstil. (In Malay). Utusan Online. Access from

[66] http://ww1.utusan.com.my/utusan/info.asp?y=2012\&dt=0 $125 \&$ pub=Utusan_Malaysia $\&$ sec $=$ Timur\&pg=wt_01.htm

[67] Zheng, Y., Chi, T. (2015). Factors influencing purchase intention towards environmentally friendly apparel: an empirical study of US consumers. International Journal of Fashion Design, Technology and Education, 8 (2), 68-77. doi:10.1080/17543266.2014.

[68] Zurga, Z., Hladnik, A., \& Tavcer, P. F. (2015). Environmentally sustainable apparel acquisition and disposal behaviours among slovenian consumers. Autex Research Journal, $15 \quad$ (4), 243-259. http://doi.org/10.1515/aut-2015-0044. 